BNL-113637-2017-JA

\title{
Tunnel-structured $\mathrm{K}_{\mathrm{x}} \mathrm{TiO}_{2}$ nanorods by in-situ carbothermal reduction as a long cycle and high rate anode for sodium-ion batteries
}

\author{
Qing Zhang, Yaqing Wei, Haotian Yang, Dong Su, \\ Ying Ma, Huiqiao Li, and Tianyou Zhai
}

Submitted to the ACS Applied Materials \& Interfaces

January 2017

Center for Functional Nanomaterials

Brookhaven National Laboratory

\author{
U.S. Department of Energy \\ USDOE Office of Science (SC), \\ Basic Energy Sciences (SC-22)
}

Notice: This manuscript has been authored by employees of Brookhaven Science Associates, LLC under Contract No. DE- SC0012704 with the U.S. Department of Energy. The publisher by accepting the manuscript for publication acknowledges that the United States Government retains a non-exclusive, paid-up, irrevocable, world-wide license to publish or reproduce the published form of this manuscript, or allow others to do so, for United States Government purposes. 


\section{DISCLAIMER}

This report was prepared as an account of work sponsored by an agency of the United States Government. Neither the United States Government nor any agency thereof, nor any of their employees, nor any of their contractors, subcontractors, or their employees, makes any warranty, express or implied, or assumes any legal liability or responsibility for the accuracy, completeness, or any third party's use or the results of such use of any information, apparatus, product, or process disclosed, or represents that its use would not infringe privately owned rights. Reference herein to any specific commercial product, process, or service by trade name, trademark, manufacturer, or otherwise, does not necessarily constitute or imply its endorsement, recommendation, or favoring by the United States Government or any agency thereof or its contractors or subcontractors. The views and opinions of authors expressed herein do not necessarily state or reflect those of the United States Government or any agency thereof. 


\section{Tunnel-structured $\mathrm{K}_{\mathrm{x}} \mathrm{TiO}_{2}$ nanorods by in-situ}

\section{carbothermal reduction as a long cycle and high rate}

\section{anode for sodium-ion batteries}

Qing Zhang, ${ }^{\dagger}$ Yaqing Wei, ${ }^{\dagger}$ Haotian Yang, ${ }^{\dagger}$ Dong Su, ${ }^{s}$ Ying Ma, ${ }^{\dagger}$ Huiqiao Li, ${ }^{\prime,}$ and Tianyou Zhai ${ }^{\prime}$

† State Key Laboratory of Material Processing and Die \& Mould Technology, School of Materials Science and Engineering, Huazhong University of Science and Technology (HUST), Wuhan 430074, Hubei, P. R. China.

${ }^{\S}$ Brookhaven National Laboratory, Upton, New York 11973, USA

* Corresponding author e-mail: hqli@hust.edu.cn (H. Q. Li)

KEYWORDS: sodium ion batteries, anode, hollandite, carbothermal reduction, tunnel structure, long cycle, high rate 


\section{ABSTRACT:}

The low electronic conductivity and the sluggish sodium-ion diffusion in the compact crystal structure of Ti-based anodes seriously restrict their development in sodium ion batteries. In this study, a new hollandite $\mathrm{K}_{\mathrm{x}} \mathrm{TiO}_{2}$ with large $(2 \times 2)$ tunnels is synthesized by a facile carbothermal reduction method and its sodium storage performance is investigated. XRD and TEM analysis illustrate the formation mechanism of the hollandite $\mathrm{K}_{\mathrm{x}} \mathrm{TiO}_{2}$ upon carbothermal reduction process. Compared to the traditional layered or small $(1 \times 1)$ tunnel-type Ti-based materials, the hollandite $\mathrm{K}_{\mathrm{x}} \mathrm{TiO}_{2}$ with large $(2 \times 2)$ tunnels may accommodate more sodium ions and facilitate the $\mathrm{Na}^{+}$diffusion in the structure, thus is expected to get a large capacity and realize high rate capability. The synthesized $\mathrm{K}_{\mathrm{x}} \mathrm{TiO}_{2}$ with large $(2 \times 2)$ tunnels shows a stable reversible capacity

of $131 \mathrm{mAh} \mathrm{g}^{-1}$ (nearly 3 times of $(1 \times 1)$ tunnels structured $\mathrm{Na}_{2} \mathrm{Ti}_{6} \mathrm{O}_{13}$ ), and superior cycling stability with no obviously capacity decay even after 1000 cycles, which is significantly better than the traditional layered $\mathrm{Na}_{2} \mathrm{Ti}_{3} \mathrm{O}_{7}$ (only $40 \%$ of capacity retention in 20 cycles). Moreover, the carbothermal process can naturally introduce oxygen vacancy and low-valent titanium as well as surface carbon coating layer to the structure, which would greatly enhance the electronic conductivity of $\mathrm{K}_{\mathrm{x}} \mathrm{TiO}_{2}$, thus endow this material high rate capability. With a good rate capability and long cyclability, this hollandite $\mathrm{K}_{\mathrm{x}} \mathrm{TiO}_{2}$ can serve as a new promising anode material for room-temperature long-life sodium-ion batteries for large-scale energy storage systems. And the carbothermal reduction method is believed an effective and facile way to develop novel Ti-based anodes with simultaneously carbon coating and Ti(III) self-doping. 


\section{INTRODUCTION}

Sodium ion batteries (SIBs) have been expected to be the most promising alternative to the traditional lithium ion batteries (LIBs) in electronic devices and large scale energy storage for the abundant sodium sources and similarities with LIBs. ${ }^{1-4}$ Unfortunately, for the larger diameter of sodium ion than that of lithium ion, it is very difficult to seek for an appropriate negative materials with excellent comprehensive performances like the role acted by graphite anode in commercial LIBs. ${ }^{5-7}$ Considering the wide abundance, low cost, low toxicity and high safety free from $\mathrm{Na}$ dendrite, Ti-based anodes have been widely researched and regarded as a very promising choice for sodium-ion anode. ${ }^{8-14}$ Currently, most of the reported titanate-based anodes possess two-dimensional layered structure or small tunnel-type structure composed by edgeshared $\mathrm{TiO}_{6}$ octahedra chains. ${ }^{5}$ Such compact crystal structure with small interlayer space and tight tunnels accounts for quite sluggish sodium-ion diffusion, which in turn leads to a poor rate performance. As well, the small interlayer spacing determines insufficient insertion sites for $\mathrm{Na}^{+}$ which especially has a much larger size than $\mathrm{Li}^{+}$. And the insertion of $\mathrm{Na}^{+}$may cause structural rearrangement during the electrode redox process, resulting in the capacity fading upon cycling. ${ }^{15}$

To promote the ion diffusion and increase the reactivity of sodium storage, fabricating nanostructure is the most-frequently used way. ${ }^{16,17}$ For example, nanostructures as $\mathrm{Na}_{2} \mathrm{Ti}_{3} \mathrm{O}_{7}$

nanotubes, ${ }^{18,19} \mathrm{Na}_{2} \mathrm{Ti}_{3} \mathrm{O}_{7}$ nanoarrays, ${ }^{20} \mathrm{H}_{2} \mathrm{Ti}_{3} \mathrm{O}_{7}$ nanobelts, ${ }^{21} \mathrm{~K}_{2} \mathrm{Ti}_{6} \mathrm{O}_{13}$ ultrafine nanowires ${ }^{22}$ have been developed to boost the electrochemical performances of Ti-based anodes for their large reaction surface area to $\mathrm{Na}^{+}$flux and high ion accessibility. The developed nanostructure can tremendously shorten the $\mathrm{Na}^{+}$diffusion length in the structure and provide high contact area with the electrolyte, thus deliver a much enhanced capacity and high rate capability for sodium 
storage. However, the morphology optimization from bulk phase to nanostructure can largely increase the surface/interface $\mathrm{Na}^{+}$storage, it change little the amount of inherent $\mathrm{Na}^{+}$ intercalation sites in the structure. Besides, most nanostructures cannot afford high temperature calcination. These wet-chemistry synthesized nanomaterials are usually in a limited crystalline nature with many lattice defects. Although a considerable capacity may be contributed by the large reaction surface and rich crystal defects, this additional capacity tends to decay upon the long cycle process due to the gradually lost activity and structure collapse of the nanostructure. Therefore, designing a more open structure with large diffusion tunnels and more accessible insertion sites is a more preferred way to develop high performance materials for SIBs.

The $\mathrm{K}_{\mathrm{x}} \mathrm{TiO}_{2}(0<\mathrm{x}<1)$ hollandite structure possesses an adequate $(2 \times 2)$ tunnel structure formed by double chains of edge-sharing $\mathrm{TiO}_{6}$ octahedra that share corners with neighboring chains, and low content $\mathrm{K}$ ions is in the tunnel space. ${ }^{23,24}$ Compared to the traditional layered or small $(1 \times 1)$ tunnel-type Ti-based materials, ${ }^{10,}{ }^{12}$ the larger $(2 \times 2)$ tunnels in the hollandite $\mathrm{K}_{\mathrm{x}} \mathrm{TiO}_{2}$ may accommodate more sodium ions and facilitate the $\mathrm{Na}^{+}$diffusion in the structure, thus is expected to get a large capacity and realize high rate capability. And the threedimensional tunnel structure also possesses stronger skeleton stability than the two-dimensional structure upon ion insertion/extraction, which would favor a better cycle stability. Unfortunately, the reported synthesis of $\mathrm{K}_{\mathrm{x}} \mathrm{TiO}_{2}$ seems harsh and high demands of safety ensurance since it involves the high temperature annealing in Ar- $\mathrm{H}_{2}$ flow. ${ }^{25-27}$ To our knowledge, little research has been done on the electrochemical properties of such a hollandite structure with $(2 \times 2)$ tunnels for SIB up to now.

Herein, we successfully synthesize hollandite $\mathrm{K}_{\mathrm{x}} \mathrm{TiO}_{2}$ by a mild cost-saving carbothermal reduction route and investigate its sodium storage performance. The obtained $\mathrm{K}_{\mathrm{x}} \mathrm{TiO}_{2}$ holds a 
nanorod morphology with simultaneously a high crystalline degree. More important, the in-situ carbothermal reduction process can not only coat a thin carbon layer on the material surface, but also introduce $\mathrm{Ti}^{3+}$-doping and oxygen vacancy in the crystal lattice, which both solidly promote the electronic conductivity of the material. ${ }^{29-32}$ When served as an anode material for SIB, the hollandite $\mathrm{K}_{\mathrm{x}} \mathrm{TiO}_{2}$ shows a reversible capacity of $131 \mathrm{mAh} \mathrm{g}^{-1}$, (nearly 3 times of $(1 \times 1)$ tunnels structured $\left.\mathrm{Na}_{2} \mathrm{Ti}_{6} \mathrm{O}_{13}\right),{ }^{12}$ and good rate capability up to $1000 \mathrm{~mA} \mathrm{~g}^{-1}$, Upon 1000 cycles, its capacity can keep very well with neither capacity decay nor voltage shift, which is significantly better than the traditional layerd $\mathrm{Na}_{2} \mathrm{Ti}_{3} \mathrm{O}_{7}$ (only $40 \%$ of capacity retention in 20 cycles) and also exceeds most reported Ti-based anodes. ${ }^{10}$

\section{EXPERIMENTAL SECTION}

Synthetic procedures. Firstly, the precursor nanowires were synthesized via a traditional hydrothermal method using potassium hydroxide and tetrabutyl titanate as the potassium and titanium sources, respectively. ${ }^{22}$ Then, the as-prepared white powders were mixed with glucose in ethanol. The weight ratio of glucose/precursor nanowires in the mixture is $5 / 8$, and the concentration of glucose in ethanol is $1.875 \mathrm{mg} / \mathrm{mL}$. After stirred for $5 \mathrm{~h}$, the suspension was then dried at $60^{\circ} \mathrm{C}$ for $12 \mathrm{~h}$ under ambient conditions. Finally, the mixture was heated at $800{ }^{\circ} \mathrm{C}$ for $6 \mathrm{~h}$ under $\mathrm{N}_{2}$ atmosphere.

Materials characterization. Powder X-ray diffraction (PXRD) patterns were recorded at room temperature with a PANalytical B.V. Empyrean diffractometer. The crystal structures were refined using the Rietveld method using the GSAS software package. The morphology of the product was examined by scanning electron microscopy (SEM, FEI Sirion 200) and highresolution transmission electron microscopy (TEM, JEM 2100, JEOL). The surface state of these samples was investigated using X-ray photoelectron spectroscopy (XPS, Kratos AXIS-ULTRA 
DLD-600 W). The thermogravimetric analysis (TG) was performed under air at a heating rate of $10{ }^{\circ} \mathrm{C} \mathrm{min}{ }^{-1}$ with a PerkinElmer Instruments Pyrisl TGA. The elements ratio of sample was obtained by Inductively Coupled Plasma-Atomic Emission Spectrometry (ICP-AES) on Optima 4300DV (Perkin-Elmer).

Electrochemical measurement. Electrochemical measurements were performed using 2032 coin-type cells with thin sodium metal used as both the reference and counter electrodes. $1 \mathrm{M}$ sodium hexafluorophosphate $\left(\mathrm{NaPF}_{6}\right)$ in $\mathrm{EC}$ (Ethylene Carbonate): DEC (Dimethyl Carbonate) with FEC (Fluoro Ethylene Carbonate) was used as electrolyte. The $\mathrm{K}_{\mathrm{x}} \mathrm{TiO}_{2}$ electrodes were fabricated by mixing $70 \mathrm{wt} . \%$ of the active material, $20 \mathrm{wt} . \%$ of $\mathrm{C} 45$, and $10 \mathrm{wt} . \%$ poly (vinylidene fluoride) (PVDF) in N-methyl-2-Pyrrolidone (NMP). The obtained slurries were coated uniformly onto copper foils and then dried in a vacuum oven at $80{ }^{\circ} \mathrm{C}$ for $12 \mathrm{~h}$ to remove the solvent before pressing. Finally the electrode film was punched into disks of $10 \mathrm{~mm}$ in diameter for half-cell tests. Cyclic voltammetry (CV) studies were carried out at room temperature using CHI660e electrochemical workstation at a scan rate of $0.1 \mathrm{mV} \mathrm{s}^{-1}$ in the voltage window $0.01-3 \mathrm{~V}$ vs. $\mathrm{Na}^{+} / \mathrm{Na}$. Galvanostatic charge/discharge measurements were performed in a voltage range of $0.01-3 \mathrm{~V}$ vs. $\mathrm{Na}^{+} / \mathrm{Na}$ at different current densities on the automatic battery testing system LAND CT2001A model. The dQ/dV tests were carried out on an automatic battery testing system of Hokuto Denko (HJ1001SD8).

\section{RESULTS AND DISCUSSION}

Figure 1a shows the XRD patterns of the precursor and its heating products obtained at different annealing conditions. The as-prepared precursor by hydrothermal method shows broad XRD peaks, indicating its low crystallinity and tiny particle size. When heated without the presence of carbon source, the diffraction peaks grow rapidly in intensity and more peaks can be 
detected. All the detected peaks can be well indexed to the $\mathrm{K}_{2} \mathrm{Ti}_{6} \mathrm{O}_{13}$ phase, which suggests that the as-prepared precursor is a low crystalline $\mathrm{K}_{2} \mathrm{Ti}_{6} \mathrm{O}_{13}$. Interestingly, when carbon source is introduced to the heat treatment process at $800{ }^{\circ} \mathrm{C}$ for $4 \mathrm{~h}$, the XRD patterns show obviously different characteristic peaks. It can be seen that a new phase $\left(\mathrm{K}_{\mathrm{x}} \mathrm{TiO}_{2}\right)$ in addition to $\mathrm{K}_{2} \mathrm{Ti}_{6} \mathrm{O}_{13}$ appears. The observed co-existence of two phases in the intermediate product clearly demonstrates the reduction strength of carbon at high temperature. With prolonged heat treatment $\left(800{ }^{\circ} \mathrm{C}\right.$ for $\left.6 \mathrm{~h}\right)$, the $\mathrm{K}_{2} \mathrm{Ti}_{6} \mathrm{O}_{13}$ phase completely disappears and all the detected diffraction peaks in the XRD pattern can be indexed to the hollandite $\mathrm{K}_{\mathrm{x}} \mathrm{TiO}_{2}$ on the basis of tetragonal symmetry space group of $\mathrm{I} 4 / \mathrm{m}$. The above results suggest the completely phase transformation from $\mathrm{K}_{2} \mathrm{Ti}_{6} \mathrm{O}_{13}$ to $\mathrm{K}_{\mathrm{x}} \mathrm{TiO}_{2}$ after $6 \mathrm{~h}$ carbothermal reduction treatment.

Figure $1 \mathrm{~b}$ shows the schematic crystal structures of the as-prepared precursor and its carbothermal reduction product. By carbothermal reduction process, the $\mathrm{K}_{2} \mathrm{Ti}_{6} \mathrm{O}_{13}$ precursor with $(1 \times 1)$ tunnels transforms to the hollandite $\mathrm{K}_{\mathrm{x}} \mathrm{TiO}_{2}$ with $(2 \times 2)$ tunnels. The hollandite-type structure comprises double chains of $\mathrm{TiO}_{6}$ octahedra forming $(2 \times 2)$ tunnels, which has been proved to be suitable for the reversible insertion/extraction of lithium ions. ${ }^{23}$ In order to determine the positions and content of $\mathrm{K}$ ions in the tunnels, the Rietveld refinement of the structure has been carried out as shown in Figure S1 and Table S1. The refinement results show that $\mathrm{K}$ is on the $2 \mathrm{~b}$ sites $(0,0,1 / 2)$ and $\mathrm{Ti}, \mathrm{O} 1$, and $\mathrm{O} 2$ on the $8 \mathrm{~h}$ sites $(\mathrm{x}, \mathrm{y}, 0)$ and $\mathrm{K}$ atom is located in the center of the tunnel space of $\mathrm{K}_{\mathrm{x}} \mathrm{TiO}_{2}$, which is well consistent with the previous reports. The resulting $\mathrm{R}$ factors reaches $w \mathrm{Rp}=0.0468, \mathrm{Rp}=0.0303$, and the refined lattice parameters are listed in Table S1. The results, in general, give a nominal chemical composition of $\mathrm{K}_{0.25} \mathrm{TiO}_{2}$, which is closely matching the EDS result $\left(\mathrm{K}_{0.26} \mathrm{TiO}_{2}\right)$ Figure S2. Compared to the $(1 \times 1)$ tunnels of $\mathrm{K}_{2} \mathrm{Ti}_{6} \mathrm{O}_{13}$ precursor, the larger $(2 \times 2)$ tunnels of the hollandite $\mathrm{K}_{\mathrm{x}} \mathrm{TiO}_{2}$ would 
provide a privileged pathway for $\mathrm{Na}$ ions diffusion. In view of this, it is expected that $\mathrm{K}_{\mathrm{x}} \mathrm{TiO}_{2}$ would be more favorable for the incorporation and diffusion of $\mathrm{Na}$ ions when used in sodium ion batteries. Furthermore, the unique large $(2 \times 2)$ tunnel structure may also help to tolerate the structural strains upon $\mathrm{Na}^{+}$insertion/extraction, which can favor a superior cycling stability.

The morphology changes before and after carbothermal reduction are revealed in Figure 2. Before heat treatment, the as-prepared low crystalline $\mathrm{K}_{2} \mathrm{Ti}_{6} \mathrm{O}_{13}$ precursor is composed of microsized spherical particles which are radially assembled by uniform ultrafine nanowires of 5$10 \mathrm{~nm}$ in diameter, as shown in Figure 2a. After carbothermal reduction, the spherical particle morphology mainly keep the same, while, the nanowires grow to nanorods. TEM images in Figure $2 \mathrm{c}$ and $\mathrm{d}$ further reveal that the nanorods possess an average diameter of 50-100 nm, much larger than its precursor due to the size growth during high temperature. Detailed analysis by HRTEM in Figure 2e and $\mathrm{f}$ demonstrates that the surface of the nanorods is coated by a carbon layer about $3 \mathrm{~nm}$. The energy dispersive X-ray elemental mappings of an individual nanorod in Figure S3 further exhibit that $\mathrm{K}, \mathrm{Ti}, \mathrm{O}$ elements are homogeneously distributed and the carbon is mainly distributed on the surface of nanorod. The carbon content of the sample is about $14.4 \%$ according to the TG test of the final products under air atmosphere. (Figure S4) The highly ordered lattice fringes with their spacing about $0.51 \mathrm{~nm}$ and $0.32 \mathrm{~nm}$ respectively coincide with the (200) and (130) facet of $\mathrm{K}_{\mathrm{x}} \mathrm{TiO}_{2}$, suggesting a high crystallization of the product obtained by the carbothermal reduction process.

To investigate the formation mechanism of the hollandite $\mathrm{K}_{\mathrm{x}} \mathrm{TiO}_{2}$, we did the TEM observation on the products obtained at different stage of carbothermal reduction process, as shown in Figure 3. At the initial stage of heat treatment $\left(800{ }^{\circ} \mathrm{C}\right.$ for $2 \mathrm{~h}$ ), (Figure 3a), the ultrafine nanowires of $\mathrm{K}_{2} \mathrm{Ti}_{6} \mathrm{O}_{13}$ precursor grow to nanorods with increased crystalline at the same time. 
The clear lattice fringes with interplanar spacing of $0.64 \mathrm{~nm}$ corresponds to (20-1) plane, well indicating the high crystalline of $\mathrm{K}_{2} \mathrm{Ti}_{6} \mathrm{O}_{13}$. Besides, it is noted that the surface of the nanorods has been coated by a thin carbon layer attributed to the pyrolysis of organic carbon source (as presented in scheme I). With prolonged heat treatment, as shown in Figure 3b, the size of nanorods increase gradually and the interplanar angle of (110) and (20-1) is $69^{\circ}$, corresponding to the $\mathrm{K}_{2} \mathrm{Ti}_{6} \mathrm{O}_{13}$ phase. However, a new lattice fringes different from the main phase on the surface of nanorods are observed, implying the surface reduction caused by the carbon. With further heat treatment for $4 \mathrm{~h}$ at $800{ }^{\circ} \mathrm{C}$, the nanorod are found to contain two obviously different phases as demonstrated in Figure $3 \mathrm{c}$, showing a partially structural rearrangement inside the nanorod in the case of insufficient carbothermal reduction time. The phase in one side of the nanorod with the lattice spacing of $0.32 \mathrm{~nm}$ matches well with the $\mathrm{K}_{\mathrm{x}} \mathrm{TiO}_{2}$ structure with its surface clearly coated by a carbon layer. While, the residue part of the nanorod corresponds to a different phase lattice, as illustrating in scheme III. Furthermore, the formed $\mathrm{K}_{\mathrm{x}} \mathrm{TiO}_{2}$ demonstrates a highly crystalline. Based on the discussion above, it can be concluded that the reduction strength of carbon at high temperature is enough to initiate the phase transformation from $(1 \times 1)$ tunnels $\mathrm{K}_{2} \mathrm{Ti}_{6} \mathrm{O}_{13}$ to $(2 \times 2)$ tunnels $\mathrm{K}_{\mathrm{x}} \mathrm{TiO}_{2}$ from surface to bulk. These observations are in well accordance with the results of XRD analysis.

Based on the above XRD and TEM analysis, we speculate that the formation of the hollandite $\mathrm{K}_{\mathrm{x}} \mathrm{TiO}_{2}$ undergoes the schematic process as shown in Figure 4. The carbothermal reduction process can be divided into three steps. Firstly, the low crystalline ultrafine precursor nanowires grow to nanorods with increased crystalline upon annealing process, at the same time, their surface is coated by a carbon layer derived from the pyrolysis of carbon source as shown in step I. Then, $\mathrm{K}_{2} \mathrm{Ti}_{6} \mathrm{O}_{13}$ nanorods are transforming to $\mathrm{K}_{\mathrm{x}} \mathrm{TiO}_{2}$ through surface reduction process 
with prolonged heat treatment as illustrated in Step II. At last, step III schemes that $\mathrm{K}_{2} \mathrm{Ti}_{6} \mathrm{O}_{13}$ nanorods have transformed to $\mathrm{K}_{\mathrm{x}} \mathrm{TiO}_{2}$ completely at the final stage of heat treatment. During the whole heat treatment process, carbon source functions with two important roles on the formation of $\mathrm{K}_{\mathrm{x}} \mathrm{TiO}_{2}$ : (i) the reducing power of carbon when heated with $\mathrm{K}_{2} \mathrm{Ti}_{6} \mathrm{O}_{13}$ may lead to the generation of oxygen vacancy on the surface, which promotes the bulk phase transformation from $\mathrm{K}_{2} \mathrm{Ti}_{6} \mathrm{O}_{13}$ to hollandite $\mathrm{K}_{\mathrm{x}} \mathrm{TiO}_{2}$ with mixed-valence (Ti(IV)/Ti(III)); and (ii) during the heat treatment process, the carbonization not only reduced the surface $\mathrm{Ti}(\mathrm{IV})$ to $\mathrm{Ti}(\mathrm{III})$, but also formed a carbon layer on the surface of $\mathrm{K}_{\mathrm{x}} \mathrm{TiO}_{2}$. The resulted mixed-valent titanium can enhance the intrinsic electronic conductivity, and the in-situ coated surface carbon layer improves the electronic conductivity between particles. The presence of $\mathrm{Ti}(\mathrm{III})$ and surface coating layer, together with the large tunnel structure, endow the hollandite $\mathrm{K}_{\mathrm{x}} \mathrm{TiO}_{2}$ both good conductivity and large reactivity towards sodium ion storage.

Electrochemical Na-storage performances of the hollandite $\mathrm{K}_{\mathrm{x}} \mathrm{TiO}_{2}$ electrode are evaluated as shown in Figure 5. The cyclic voltammetry (CV) exhibits two pairs of obvious redox peaks at the potential of $0.8 / 0.5 \mathrm{~V}$ and 1.3/1.2 V, respectively (see Figure 5a). The reversible redox peaks at lower potentials about $0.01 / 0.08 \mathrm{~V}$ can be assigned to the $\mathrm{Na}$ ion intercalation in conductive additive (C45). ${ }^{33}$ And the position of redox peaks almost keep no change for the following continuous sweeps, suggesting the highly reversible insertion/extraction reaction. A broad shoulder peak at about $0.8 \mathrm{~V}$ is observed in the first sodiation scan and disappears in the second sodiation scan, which may be associated with the formation of a solid-electrolyte interface (SEI) film due to irreversible reduction of the electrolyte. ${ }^{34}$ The rate capability of $\mathrm{K}_{\mathrm{x}} \mathrm{TiO}_{2}$ at different rates is displayed in Figure $5 \mathrm{~b}$ and c. As the current density increases from 20 to $1000 \mathrm{~mA} \mathrm{~g}^{-1}$, the shape discharge/charge profile is well preserved at different current density, indicating the 
stable host structure even over fast $\mathrm{Na}^{+}$insertion/extraction. And the charge/discharge curves are in well correspondence with the redox peaks in the CV curves. It exhibits a reversible capacity of $131 \mathrm{mAh} \mathrm{g}^{-1}$ at a small current of $20 \mathrm{~mA} \mathrm{~g}^{-1}$, (nearly 3 times of $(1 \times 1)$ tunnels structured $\left.\mathrm{Na}_{2} \mathrm{Ti}_{6} \mathrm{O}_{13}\right),{ }^{12}$ even at a high density of $1000 \mathrm{~mA} \mathrm{~g}^{-1}, 51 \%$ of the initial capacity $\left(67 \mathrm{mAh} \mathrm{g}^{-1}\right)$ can be maintained. In contrast, at the same current density of $20 \mathrm{~mA} \mathrm{~g}{ }^{-1}$, the bulk $\mathrm{K}_{2} \mathrm{Ti}_{6} \mathrm{O}_{13}$ with small $(1 \times 1)$ tunnels only delivers a capacity of $67 \mathrm{mAh} \mathrm{g}^{-1}{ }^{22}$ J. C. $\mathrm{P}^{\prime}$ erez-Flores and coworkers also reported the electrochemical performance of hollandite $\mathrm{TiO}_{2}-\mathrm{H}$ obtained with solid state synthesis. ${ }^{24}$ It only exhibits a reversible charge-discharge capacity of $85 \mathrm{~mA} \mathrm{~h} \mathrm{~g}^{-1}$ at $\mathrm{C} / 8$ $\left(41 \mathrm{~mA} \mathrm{~g}^{-1}\right)$ rate in the $2.5-0.2 \mathrm{~V}$ voltage range, and the capacity decayed fast within few cycles. The higher reversible capacity of hollandite $\mathrm{K}_{\mathrm{x}} \mathrm{TiO}_{2}$ should be attributed to its larger $(2 \times 2)$ tunnels and higher electronic conductivity. Figure 5d displays the long cycling performance of the hollandite $\mathrm{K}_{\mathrm{x}} \mathrm{TiO}_{2}$. Even after 1000 cycles, no obviously capacity decay is observed at a current density of $200 \mathrm{~mA} \mathrm{~g}^{-1}$ and the coulombic efficiency remains nearly $100 \%$ during cycling. As far as we know, this impressive long-term cyclic stability is better than those of most reported Ti-based anodes for sodium-ion batteries. ${ }^{35-37}$

Figure 6 exhibits the rate capability comparison of low crystalline $\mathrm{K}_{2} \mathrm{Ti}_{6} \mathrm{O}_{13}$ and the hollandite $\mathrm{K}_{\mathrm{x}} \mathrm{TiO}_{2}$. Even at a large current density of $1000 \mathrm{~mA} \mathrm{~g}^{-1}$, the $\mathrm{K}_{\mathrm{x}} \mathrm{TiO}_{2}$ still can keep $51 \%$ of the initial capacity $\left(67 \mathrm{mAh} \mathrm{g}^{-1}\right)$, higher than $33 \%$ of the $\mathrm{K}_{2} \mathrm{Ti}_{6} \mathrm{O}_{13}$ nanowires. Although the $\mathrm{K}_{2} \mathrm{Ti}_{6} \mathrm{O}_{13}$ nanowires possess larger specific area due to its ultrafine nanowires with a diameter of only 5-10 nm, the hollandite $\mathrm{K}_{\mathrm{x}} \mathrm{TiO}_{2}$ nanorods with an average diameter of 50-100 nm exhibits better rate performance instead. This indicates that such good rate performance should be ascribed to the open structure and enhanced electronic conductivity of $\mathrm{K}_{\mathrm{x}} \mathrm{TiO}_{2}$ rather than the nanosize effect. 
It is believed that the presence of $\mathrm{Ti}^{3+}$ can significantly enhance the inherent electronic conductivity and carbon thermal reduction can effectively introduce low-valent titanium to the host material. ${ }^{29-32}$ Figure 7 shows the X-ray photoelectron spectroscopy (XPS) of $\mathrm{K}_{\mathrm{x}} \mathrm{TiO}_{2}$. The survey scan of XPS (Figure 7a) contains no signal of impurity elements except K, Ti, O and C. The carbon signals are ascribed to carbon coating on the surface of the sample originated from the pyrolysis of carbon source. The $\mathrm{C} 1 \mathrm{~s}$ peak is fitted by four peaks, corresponding to $\mathrm{C}-\mathrm{C}, \mathrm{C}-$ $\mathrm{O}, \mathrm{C}=\mathrm{O}$ and $\mathrm{O}-\mathrm{C}=\mathrm{O}$, respectively. ${ }^{38}$ Two additional peaks at higher binding energy $(>290 \mathrm{eV})$ in Figure $7 \mathrm{~b}$ should be attributed to $\mathrm{K} 2 \mathrm{p}_{3 / 2}$ and $\mathrm{K} 2 \mathrm{p}_{1 / 2}$. The Ti $2 \mathrm{p}$ core level spectrum shows two sets of doublets that are attributed to the presence of $\mathrm{Ti}(\mathrm{IV})$ and $\mathrm{Ti}(\mathrm{III})$, and the $\mathrm{Ti}^{3+} / \mathrm{Ti}^{4+}$ ratio is about 0.35 . As XPS is a surface-sensitive technique, we have carried out the inductively coupled plasma-atomic emission spectroscopy analyses (ICP-AES) to determine the element ratio of the bulk sample. And the ICP-AES results shows that the chemical compositions is $\mathrm{K}_{0.23} \mathrm{TiO}_{2}$. According to the law of charge conservation, we can get the $\mathrm{Ti}^{3+} / \mathrm{Ti}^{4+}$ ratio of the bulk sample is about 0.30 . The $\mathrm{O} 1 \mathrm{~s}$ spectrum in Figure $7 \mathrm{~d}$ provides auxiliary evidence of the oxygen vacancy, where the peak at $530.9 \mathrm{eV}$ belongs to the $\mathrm{O}^{2-}$ ions in the O-Ti-O lattice and a small shoulder peak at $533.2 \mathrm{eV}$ is due to the oxygen vacancy sites on the surface. Hence, the introducing of Ti(III) should be related to the formation of the oxygen vacancy induced by the reduction power of carbon. This has been supported by many previous experimental and theoretical studies. ${ }^{39-43}$ The presence of $\mathrm{Ti}^{3+}$ and oxygen vacancy together with the surface carbon coating guarantee the material both good intrinsic and surface conductivity, thus can enable a better rate performance of $\mathrm{K}_{\mathrm{x}} \mathrm{TiO}_{2}$ than the $\mathrm{K}_{2} \mathrm{Ti}_{6} \mathrm{O}_{13}$ nanowires.

The hollandite structure not only exhibits the higher capacity and better rate capability, but also shows stable reaction potential. The cycling stability can be illustrated through $d Q / d V$ 
curves as shown in Figure 8a. The two pairs of charge/discharge peaks keep no change in position during cycling and are consistent with the redox peaks of $\mathrm{CV}$ curves, suggesting a highly stable insertion/extraction reaction. The ultrahigh cycling stability may be ascribed to the rigid tunnel structure. The open tunnel structure can facilitate ion transport and tolerance of the distortion during $\mathrm{Na}^{+}$insertion/extraction. Figure 8b shows XRD patterns of the hollandite $\mathrm{K}_{\mathrm{x}} \mathrm{TiO}_{2}$ electrode before and after cycling. All the main peaks of hollandite $\mathrm{K}_{\mathrm{x}} \mathrm{TiO}_{2}$ phase are still detected even after cycling, implying that the stable tunnel structure can be well maintained upon repeated sodium insertion/extraction processes. The morphology changes in the typical electrode before and after cycling are also investigated by TEM. As revealed in Figure 8c and d, the hollandite $\mathrm{K}_{\mathrm{x}} \mathrm{TiO}_{2}$ retains its original nanorod morphology and the clear lattice fringes with unchanged spacing of $0.32 \mathrm{~nm}$ verify that the electrode still maintains its high crystallinity, indicating the robust structural stability of this material.

\section{CONCLUSION}

In summary, the hollandite $\mathrm{K}_{\mathrm{x}} \mathrm{TiO}_{2}$ nanorods with open $(2 \times 2)$ tunnels were successfully obtained by a mild cost-saving in-situ carbothermal reduction route and its sodium storage performance was investigated. The XRD and TEM analysis illustrated the formation mechanism of the hollandite $\mathrm{K}_{\mathrm{x}} \mathrm{TiO}_{2}$. When carbon source is introduced to the heat treatment process, the reducing power of carbon leads to the generation of oxygen vacancy on the surface of $\mathrm{K}_{2} \mathrm{Ti}_{6} \mathrm{O}_{13}$ precursor, which promoted the bulk phase transformation from $(1 \times 1)$ tunnel $\mathrm{K}_{2} \mathrm{Ti}_{6} \mathrm{O}_{13}$ to $(2 \times 2)$ hollandite $\mathrm{K}_{\mathrm{x}} \mathrm{TiO}_{2}$. This hollandite $\mathrm{K}_{\mathrm{x}} \mathrm{TiO}_{2}$ demonstrates a stable reversible capacity of $131 \mathrm{mAh}$ $\mathrm{g}^{-1}$ and excellent rate capability of $67 \mathrm{mAh} \mathrm{g}^{-1}$ at $1000 \mathrm{~mA} \mathrm{~g}^{-1}$ due to the privileged pathway for $\mathrm{Na}^{+}$diffusion in the open tunnel structure. And the capacity of $\mathrm{K}_{\mathrm{x}} \mathrm{TiO}_{2}$ can maintain very well with nearly no capacity decay upon 1000 cycles, demonstrating the good stability of this 
hollandite type structure. The superior capacity and rate performance of $\mathrm{K}_{\mathrm{x}} \mathrm{TiO}_{2}$ to $\mathrm{K}_{2} \mathrm{Ti}_{6} \mathrm{O}_{13}$ precursor can be attributed to the introducing of Ti(III) and oxygen vacancy by carbothermal reduction, the larger open tunnels of hollandite structure, and the existence of in-situ surface carbon coating layer. With excellent rate capability and long cyclability, this hollandite $\mathrm{K}_{\mathrm{x}} \mathrm{TiO}_{2}$ can serve as a new promising anode material for room-temperature long-life sodium-ion batteries for large-scale energy storage systems. And the carbothermal reduction method is believed an effective and facile way to develop novel Ti-based anodes with simultaneously carbon coating and Ti(III) self-doping.

\section{SUPPORTING INFORMATION}

Supporting Information. Rietveld XRD refinement results, SEM and EDS spectrum, elemental mapping images, and TG curve of the prepared $\mathrm{K}_{\mathrm{x}} \mathrm{TiO}_{2}$ sample.

\section{AUTHOR INFORMATION}

\section{Corresponding Author}

* E-mail: Prof. H.Q. Li, hqli@hust.edu.cn

\section{ACKNOWLEDGMENT}

We acknowledge the support from the National Basic Research Program of China (973 program, 2015CB932600), the National Natural Science Foundation of China (21571073, 51302099, 51551205), the Program for New Century Excellent Talents in University (NCET-13-0227), the Program for HUST Interdisplinary Innovation Team (2015ZDTD038) and the Fundamental Research Funds for the Central University. The authors also thank the Analytical and Testing Center of HUST for the measurements.

\section{REFERENCES}


1. Yabuuchi, N.; Kubota, K.; Dahbi, M.; Komaba, S. Research Development on Sodium-Ion Batteries. Chem. Rev. 2014, 114, 11636-11682.

2. Luo, W.; Shen, F.; Bommier, C.; Zhu, H. L.; Ji, X. L.; Hu, L. B. Na-Ion Battery Anodes: Materials and Electrochemistry. Acc. Chem. Res. 2016, 49, 231-240.

3. Pan, H. L.; Hu, Y. S.; Chen, L. Q. Room-temperature Stationary Sodium-ion Batteries for Large-scale Electric Energy Storage. Energy Environ. Sci. 2013, 6, 2338-2360.

4. Zhang, J. J.; Yu, A. S. Nanostructured Transition Metal Oxides as Advanced Anodes for Lithium-Ion Batteries. Sci. Bull. 2015, 60, 823-838.

5. Dahbi, M.; Yabuuchi, N.; Kubota, K.; Tokiwa, K.; Komaba, S. Negative Electrodes for Na-Ion Batteries. Phys. Chem. Chem. Phys. 2014, 16, 15007-15028.

6. Zhu, Y. J.; Wen, Y.; Fan, X. L.; Gao, T.; Han, F. D.; Luo, C.; Liou, S.-C.; Wang, C. S. Red Phosphorus-Single-Walled Carbon Nanotube Composite as a Superior Anode for Sodium Ion Batteries. ACS Nano 2015, 9, 3254-3264

7. David, L.; Bhandavat, R.; Singh, G. $\mathrm{MoS}_{2} /$ Graphene Composite Paper for Sodium-Ion Battery Electrodes. ACS Nano 2014, 8, 1759-1770.

8. Doeff, M.; Cabana, J.; Shirpour, M. Titanate Anodes for Sodium Ion Batteries. J. Inorg. Organomet Polym. 2014, 24, 5-14.

9. Kim, K.-T.; Ali, G.; Chung, K. Y.; Yoon, C. S.; Yashiro, H.; Sun, Y. K.; Lu, J.; Amine, K.; Myung, S.-T. Anatase Titania Nanorods as an Intercalation Anode Material for Rechargeable Sodium Batteries. Nano Lett. 2014, 14, 416-422.

10. Pan, H. L.; Lu, X.; Yu, X. Q.; Hu, Y. S.; Li, H.; Yang, X. Q.; Chen, L. Q. Sodium Storage and Transport Properties in Layered $\mathrm{Na}_{2} \mathrm{Ti}_{3} \mathrm{O}_{7}$ for Room-Temperature Sodium-Ion Batteries. Adv. Energy Mater. 2013, 3, 1186-1194. 
11. Su, D. W.; Dou, S. X.; Wang, G. X. Anatase $\mathrm{TiO}_{2}$ : Better Anode Material Than Amorphous and Rutile Phases of $\mathrm{TiO}_{2}$ for Na-Ion Batteries. Chem. Mater. 2015, 27, 60226029.

12. Rudola, A.; Saravanan, K.; Devaraj, S.; Gong, H.; Balaya, P. $\mathrm{Na}_{2} \mathrm{Ti}_{6} \mathrm{O}_{13}$ : A Potential Anode for Grid-Storage Sodium-Ion Batteries. Chem. Commun. 2013, 49, 7451-7453.

13. Yan, Z. C; Liu, L.; Tan, J. L.; Zhou, Q.; Huang, Z. F.; Xia, D. D.; Shu, H. B.; Yang, X. K.; Wang, X. Y. One-pot synthesis of bicrystalline titanium dioxide spheres with a core-shell structure as anode materials for lithium and sodium ion batteries. J. Power Sources 2014, $269,37-45$.

14. Yan, Z. C; Liu, L.; Shu, H. B.; Yang, X. K.; Wang, H.; Tan, J. L.; Zhou, Q.; Huang, Z. F.; Wang, X. Y. A tightly integrated sodium titanate-carbon composite as an anode material for rechargeable sodium ion batteries. J. Power Sources 2015, 274, 8-14.

15. Senguttuvan, P.; Rousse, G.; Arroyo y de Dompablo, M. E.; Vezin, H.; Tarascon, J. -M.; Palacín, M. R. Low-Potential Sodium Insertion in a NASICON-Type Structure Through the Ti (III)/Ti (II) Redox Couple. J. Am. Chem. Soc. 2013, 135, 3897-3903.

16. Yin, J.; Qi, L.; Wang, H. Y. Sodium Titanate Nanotubes as Negative Electrode Materials for Sodium-Ion Capacitors. ACS Appl. Mater. Interfaces 2012, 4, 2762-2768.

17. Prutsch, F.; Wilkening, M.; Hanzu, I. Long-Cycle-Life Na-Ion Anodes Based on Amorphous Titania Nanotubes Interfaces and Diffusion. ACS Appl. Mater. Interfaces 2015, 7, 25757-25769.

18. Zhang, Y. P.; Guo, L.; Yang, S. H. Three-Dimensional Spiderweb Architecture Assembled from $\mathrm{Na}_{2} \mathrm{Ti}_{3} \mathrm{O}_{7}$ Nanotubes as a High Performance Anode for a Sodium-Ion Battery. Chem. Commun. 2014, 50, 14029-14032. 
19. Wang, S.; Wang, W.; Zhan, P.; Yuan, Y.; Jiao, K. L.; Jiao, H. D.; Jiao, S. Q. 3D FlowerLike $\mathrm{NaHTi}_{3} \mathrm{O}_{7}$ Nanotubes as High-Performance Anodes for Sodium-Ion Batteries. J. Mater. Chem. A 2015, 3, 16528-16534.

20. Fu, S. D.; Ni, J. F.; Xu, Y.; Zhang, Q.; Li, L. Hydrogenation Driven Conductive $\mathrm{Na}_{2} \mathrm{Ti}_{3} \mathrm{O}_{7}$ Nanoarrays as Robust Binder-Free Anodes for Sodium-Ion Batteries. Nano Lett. 2016, 16, 4544-4551.

21. Tian, Q. H.; Tian, Y.; Zhang, Z. X.; Yang, L.; Hirano, S. I. Hydrogen Titanate Constructed by Ultrafine Nanobelts as Advanced Anode Materials with High-Rate and Ultra-Long Life for Lithium-Ion Batteries. RSC Adv. 2015, 5, 104275-104283.

22. Zhang, Q.; Guo, Y. P.; Guo, K.; Zhai, T. Y.; Li, H. Q. Ultrafine Potassium Titanate Nanowires: a New Ti-Based Anode for Sodium Ion Batteries. Chem. Commun. 2016, 52, 6229-6232.

23. Sakaoa, M.; Kijima, N.; Akimoto, J.; Okutani, T. Lithium Insertion and Extraction Properties of Hollandite-Type $\mathrm{K}_{\mathrm{x}} \mathrm{TiO}_{2}$ with Different $\mathrm{K}$ Content in the Tunnel Space. Solid State Ionics 2013, 243, 22-29.

24. P' erez-Flores, J. C.; Baehtz, C.; Kuhn, A.; Garc'1a-Alvarado, F. Hollandite-Type TiO 2 : a New Negative Electrode Material for Sodium-Ion Batteries. J. Mater. Chem. A 2014, 2, 1825-1833.

25. Gutierrez-Florez, M. T.; Kuhn, A.; Garcia-Alvarado, F. Lithium intercalation in $\mathrm{K}_{\mathrm{x}} \mathrm{Ti}_{8} \mathrm{O}_{16}$ compounds. Int. J. Inorg. Mater. 1999, 1, 117-121.

26. Sakao, M.; Kijima, N.; Kataoka, K.; Akimoto, J.; Okutani, T. Synthesis and Electrochemical Properties of Hollandite-type $\mathrm{K}_{\mathrm{x}} \mathrm{TiO}_{2}$. Key Eng. Mater. 2011, 485, 123126. 
27. Sakao, M.; Kijima, N.; Akimoto, J.; Okutani, T. Synthesis, Crystal structure, and Electrochemical Properties of Hollandite-type $\mathrm{K}_{0.008} \mathrm{TiO}_{2}$. Solid State Ionics 2012, 225 502505.

28. Noailles, L. D.; Johnson, C. S.; Vaughey, J. T.; Thackeray, M. M. Lithium Insertion into Hollandite-type $\mathrm{TiO}_{2}$. J. Power Sources 1999, 81-82, 259-263

29. Shen, L. F.; Uchaker, E.; Zhang X. G.; Cao, G. Z. Hydrogenated $\mathrm{Li}_{4} \mathrm{Ti}_{5} \mathrm{O}_{12}$ Nanowire Arrays for High Rate Lithium Ion Batteries. Adv. Mater. 2012, 24, 6502-6506.

30. Qiu, J. X.; Lai, C.; Gray, E.; Li, S.; Qiu, S. Y.; Strounina, E.; Sun, C. H.; Zhao, H. J.; Zhang, S. Q. Blue Hydrogenated Lithium Titanate as a High-Rate Anode Material for Lithium-Ion Batteries. J. Mater. Chem. A 2014, 2, 6353-6358.

31. Chen, J.; Song, W. X.; Hou, H. S.; Zhang, Y.; Jing, M. J.; Jia, X. N.; Ji, X. B. Ti ${ }^{3+}$ SelfDoped Dark Rutile $\mathrm{TiO}_{2}$ Ultrafine Nanorods with Durable High-Rate Capability for Lithium-Ion Batteries. Adv. Funct. Mater. 2015, 25, 6793-6801.

32. Chen, J.; Ding, Z. Y.; Wang, C.; Hou, H. S.; Zhang, Y.; Wang, C. W.; Zou, G. Q.; Ji, X. B. Black Anatase Titania with Ultrafast Sodium-Storage Performances Stimulated by Oxygen Vacancies. ACS Appl. Mater. Interfaces 2016, 8, 9142-9151.

33. Chen, K. Y.; Zhang, W. X.; Liu, Y.; Zhu, H. P.; Duan, J.; Xiang, X. H.; Xue, L. H.; Huang, Y. H. Carbon Coated $\mathrm{K}_{0.8} \mathrm{Ti}_{1.73} \mathrm{Li}_{0.27} \mathrm{O}_{4}$ : A Novel Anode Material for Sodium-Ion Batteries with a Long Cycle Life. Chem. Commun. 2015, 51, 1608-1611.

34. Fan, X. L.; Mao, J. F.; Zhu, Y. J.; Luo, C.; Suo, L. M.; Gao, T.; Han, F. D.; Liou, S. C.; Wang, C. S. Superior Stable Self-Healing $\mathrm{SnP}_{3}$ Anode for Sodium-Ion Batteries. Adv. Energy Mater. 2015, 5, 1500174. 
35. Nava-Avendaño, J.; Morales-García, A.; Ponrouch, A.; Rousse, G.; Frontera, C.; Senguttuvan, P.; Tarascon, J. M.; Arroyo-de Dompablo, M. E.; Rosa Palacín, M. Taking Steps Forward in Understanding the Electrochemical Behavior of $\mathrm{Na}_{2} \mathrm{Ti}_{3} \mathrm{O}_{7}$. J. Mater. Chem. A 2015, 3, 22280-22286.

36. Rudola, A.; Saravanan, K.; Mason, C. W.; Balaya, P. $\mathrm{Na}_{2} \mathrm{Ti}_{3} \mathrm{O}_{7}$ : an Intercalation Based Anode for Sodium-Ion Battery Applications. J. Mater. Chem. A 2013, 1, 2653-2662.

37. Shirpour, M.; Cabana, J.; Doeff, M. New Materials Based on a Layered Sodium Ttanate for Dual Electrochemical $\mathrm{Na}$ and Li Intercalation Systems. Energy Environ. Sci. 2013, 6, 2538-2547.

38. Xu, H. H.; Hu, X. L.; Luo, W.; Sun, Y. M.; Yang, Z.; Hu, C. C.; Huang, Y. H. Electrospun Conformal $\mathrm{Li}_{4} \mathrm{Ti}_{5} \mathrm{O}_{12} / \mathrm{C}$ Fibers for High-Rate Lithium-Ion Batteries. ChemElectroChem 2014, 1, 611-616.

39. Wang, Y. G.; Liu, H. M.; Wang, K. X.; Eiji, H.; Wang, Y. R.; Zhou, H. S. Synthesis and Electrochemical Performance of Nano-Sized $\mathrm{Li}_{4} \mathrm{Ti}_{5} \mathrm{O}_{12}$ with Double Surface Modification of Ti (III) and Carbon. J. Mater. Chem. 2009, 19, 6789-6795.

40. Yan, B., Li, M. S.; Li, X. F.; Bai, Z. M.; Yang, J. W.; Xiong, D. B.; Li, D. J. Novel Understanding of Carbothermal Reduction Enhancing Electronic and Ionic Conductivity of $\mathrm{Li}_{4} \mathrm{Ti}_{5} \mathrm{O}_{12}$ Anode. J. Mater. Chem. A 2015, 3, 11773-11781.

41. Xia, T.; Zhang, W.; Murowchick, J. B.; Liu, G.; Chen, X. B. A Facile Method to Improve the Photocatalytic and Lithium-Ion Rechargeable Battery Performance of $\mathrm{TiO}_{2}$ Nanocrystals. Adv. Energy Mater. 2013, 3, 1516-1523. 
42. Dong, S. Y.; Wang, X. Y.; Shen, L. F.; Li, H. S.; Wang, J.; Nie, P.; Wang, J. J.; Zhang, X. G. Trivalent Ti Self-Doped $\mathrm{Li}_{4} \mathrm{Ti}_{5} \mathrm{O}_{12}$ : a High Performance Anode Material for Lithium-Ion Capacitors. J. Electroanal. Chem. 2015, 757, 1-7.

43. Li, Y. F.; Wang, D. D.; An, Q. Y.; Ren, B.; Rong, Y. G.; Yao, Y. Flexible Electrode for Long-Life Rechargeable Sodium-Ion Batteries: Effect of Oxygen Vacancy in $\mathrm{MoO}_{3-\mathrm{x}} . J$. Mater. Chem. A 2016, 4, 5402-5405. 

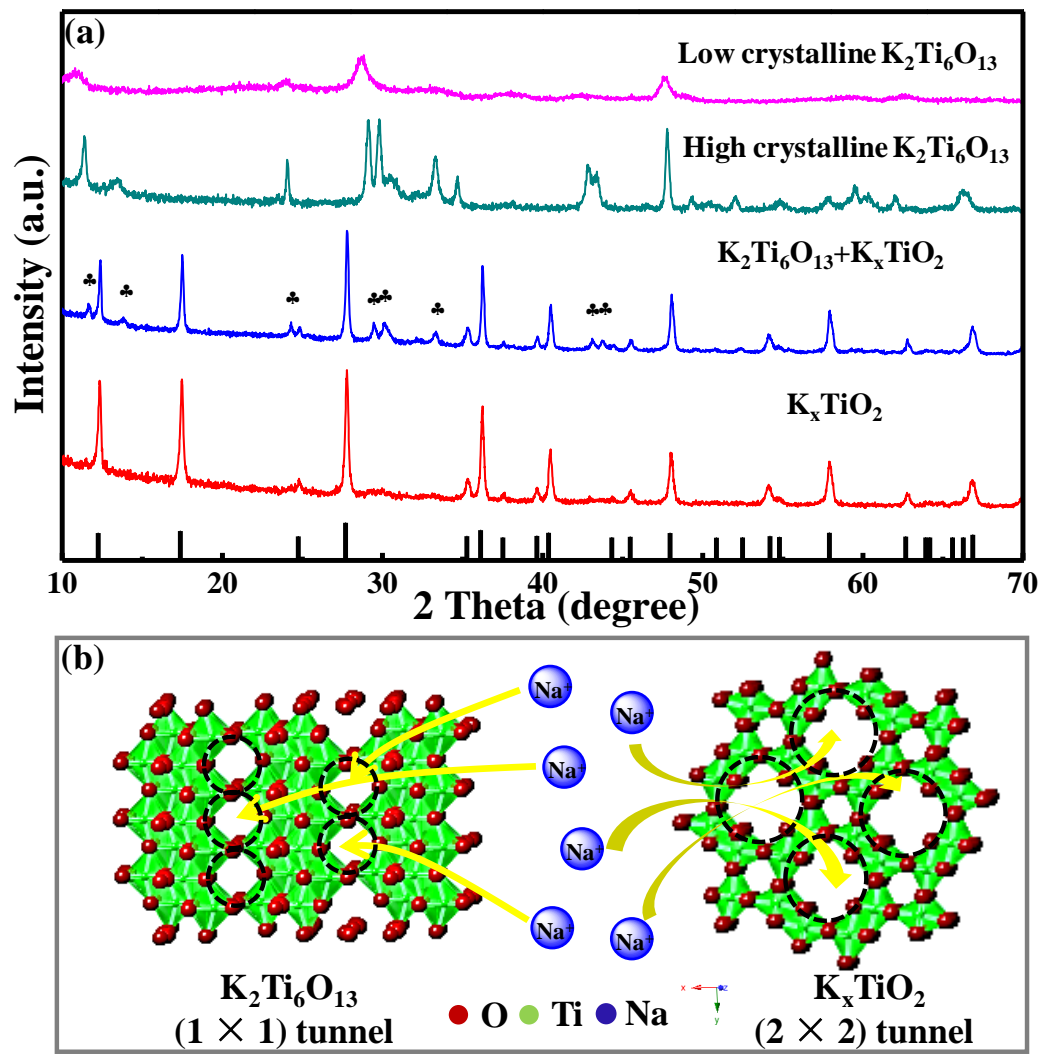

Figure 1. (a) The X-ray diffraction patterns of hydrothermal product and the products heated under different conditions. (Magenta) Low crystalline $\mathrm{K}_{2} \mathrm{Ti}_{6} \mathrm{O}_{13}$ precursor without heat treatment, (dark cyan) high crystalline $\mathrm{K}_{2} \mathrm{Ti}_{6} \mathrm{O}_{13}$ obtained at $800{ }^{\circ} \mathrm{C}$ for $6 \mathrm{~h}$ without presence of carbon source in heating, (blue) the intermediate heating product with presence of carbon source at 800 ${ }^{\circ} \mathrm{C}$ for $4 \mathrm{~h}$, (red) the final heating product with presence of carbon source at $800{ }^{\circ} \mathrm{C}$ for $6 \mathrm{~h}$. (b) Schematic structure illustration of $\mathrm{K}_{2} \mathrm{Ti}_{6} \mathrm{O}_{13}$ precursor (left) and the hollandite $\mathrm{K}_{\mathrm{x}} \mathrm{TiO}_{2}$ product (right). 

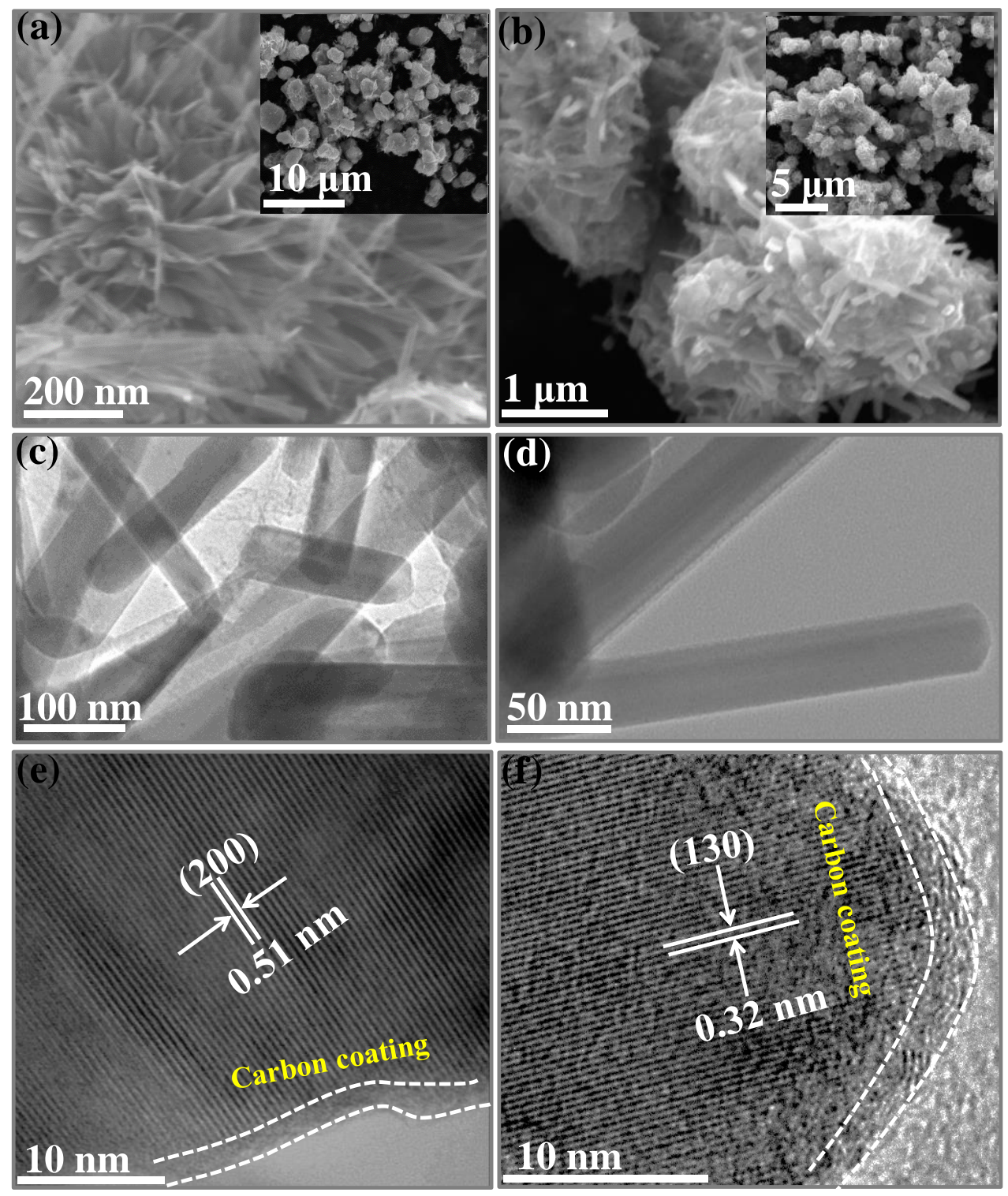

Figure 2. (a) The SEM image of low crystalline $\mathrm{K}_{2} \mathrm{Ti}_{6} \mathrm{O}_{13}$ precursor prepared via hydrothermal method, (b-f) SEM and TEM images of the hollandite $\mathrm{K}_{\mathrm{x}} \mathrm{TiO}_{2}$ sample obtained after heating with carbon source at $800{ }^{\circ} \mathrm{C}$ for $6 \mathrm{~h}$. 

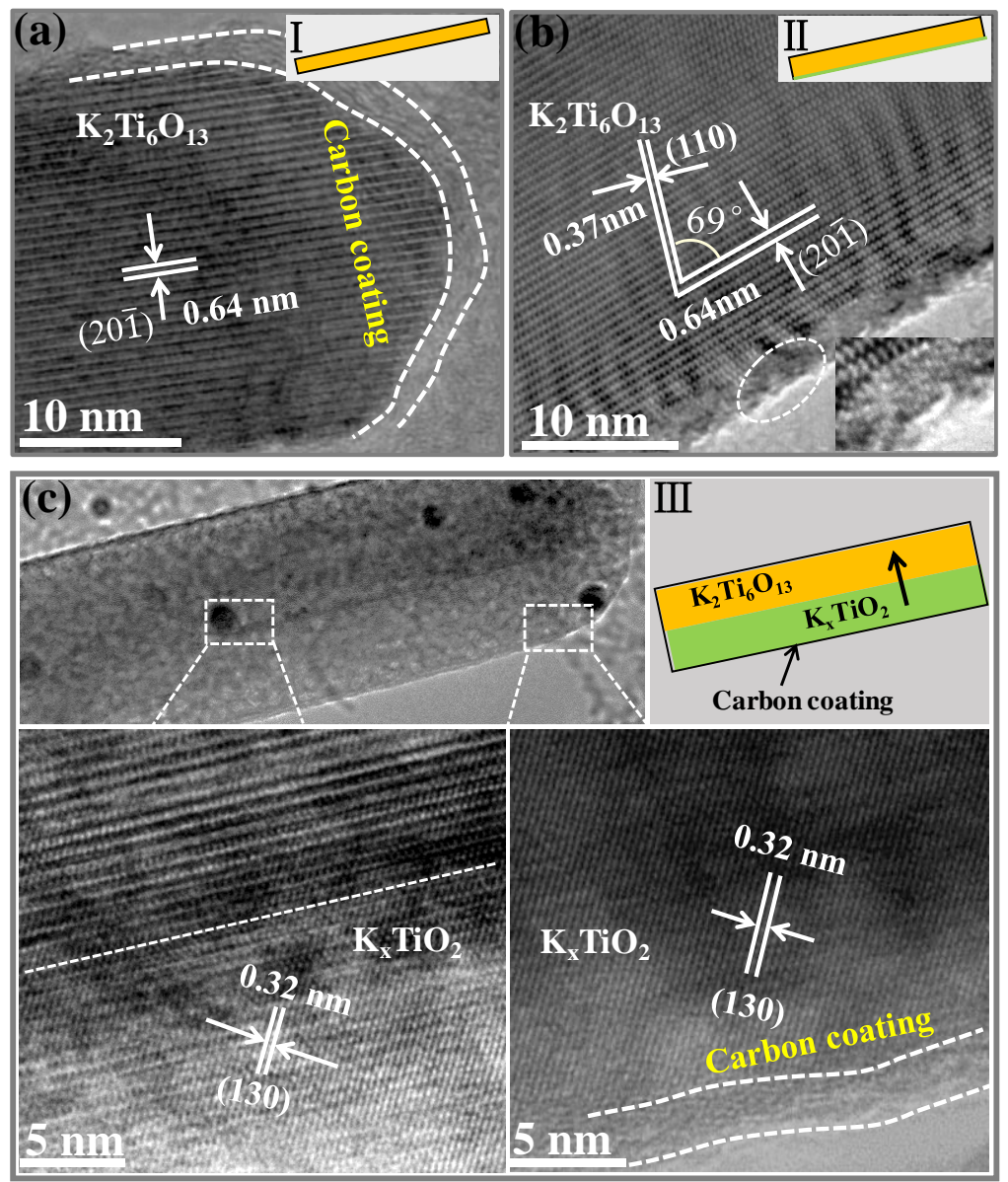

Figure 3. The HRTEM image of intermediate products obtained at different stage of the carbothermal reduction process. (a) the $\mathrm{K}_{2} \mathrm{Ti}_{6} \mathrm{O}_{13}$ nanorods obtained at the initial stage of heating the nanowire precursor with carbon source, scheme (I) represents that the nanowires has grown to nanorods with its surface coated by a carbon layer; (b) $\mathrm{K}_{2} \mathrm{Ti}_{6} \mathrm{O}_{13}$ nanorods with lattice rearrangement observed at its surface edge, scheme (II) illustrates the size growing of the $\mathrm{K}_{2} \mathrm{Ti}_{6} \mathrm{O}_{13}$ nanorod with simultaneously phase conversion occurred at the surface due to carbon reduction; (c) Further carbothermal reduction process leads to phase transformation propagating from surface to the bulk of the nanorod, scheme (III) illustrates the mixed phase lattices in the nanorod which attribute to the co-existence of the $\mathrm{K}_{2} \mathrm{Ti}_{6} \mathrm{O}_{13}$ precursor phase and the final $\mathrm{K}_{\mathrm{x}} \mathrm{TiO}_{2}$ product phase. 


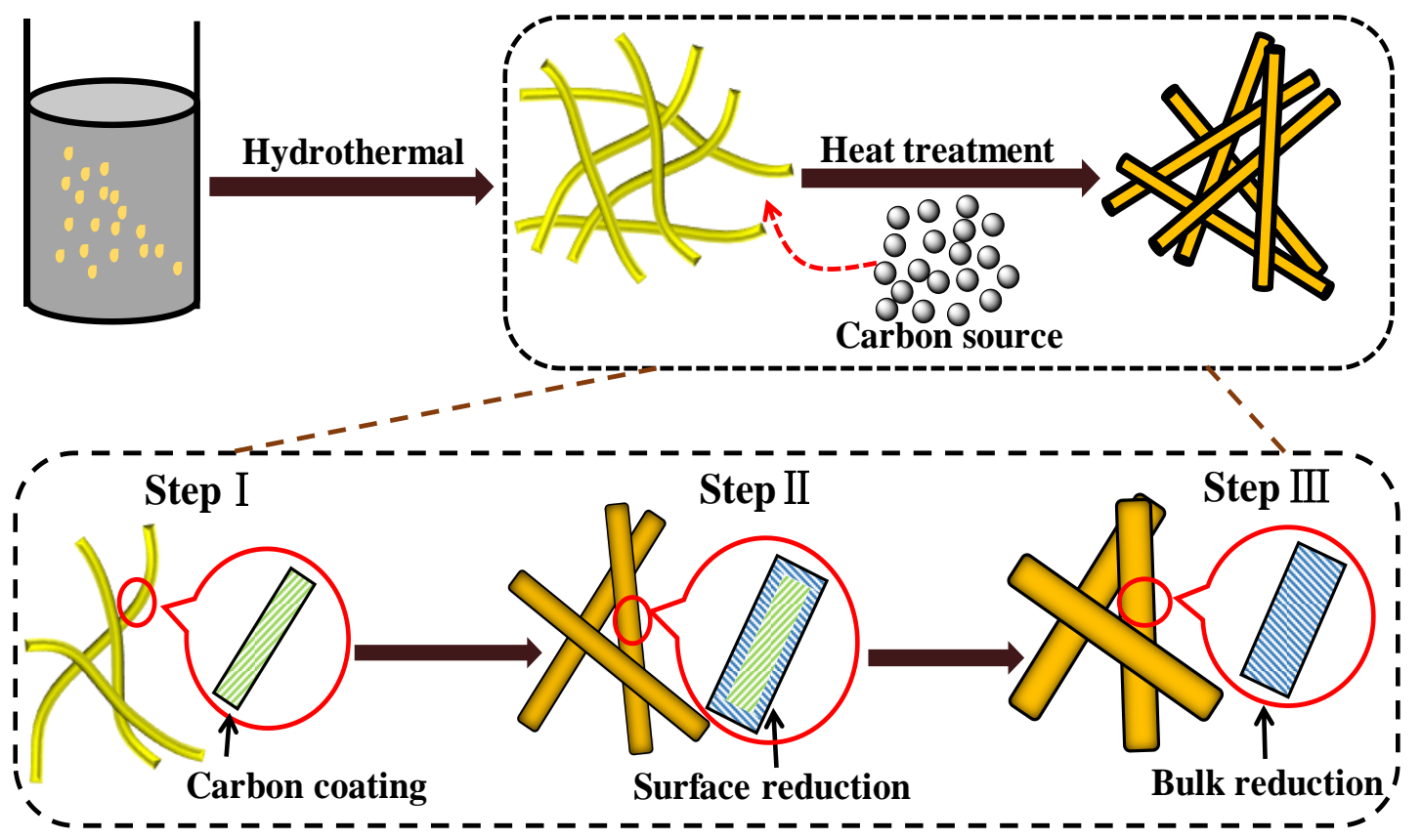

Figure 4. Schematic representation of the preparation process for the hollandite $\mathrm{K}_{\mathrm{x}} \mathrm{TiO}_{2}$. The $\mathrm{K}_{2} \mathrm{Ti}_{6} \mathrm{O}_{13}$ nanowires were synthesized via a traditional hydrothermal method, then the asprepared nanowires were mixed with glucose in ethanol and further heated at $800{ }^{\circ} \mathrm{C}$ under $\mathrm{N}_{2}$ atmosphere. Step I: The $\mathrm{K}_{2} \mathrm{Ti}_{6} \mathrm{O}_{13}$ nanowires grew to nanorods with increased crystalline and were coated by a carbon layer at the initial stage of heat treatment. Step II: $\mathrm{K}_{2} \mathrm{Ti}_{6} \mathrm{O}_{13}$ nanorods are transforming to $\mathrm{K}_{\mathrm{x}} \mathrm{TiO}_{2}$ through surface reduction process with prolonged heat treatment. Step III: $\mathrm{K}_{2} \mathrm{Ti}_{6} \mathrm{O}_{13}$ nanorods have transformed to $\mathrm{K}_{\mathrm{x}} \mathrm{TiO}_{2}$ completely at the final stage of heat treatment. 

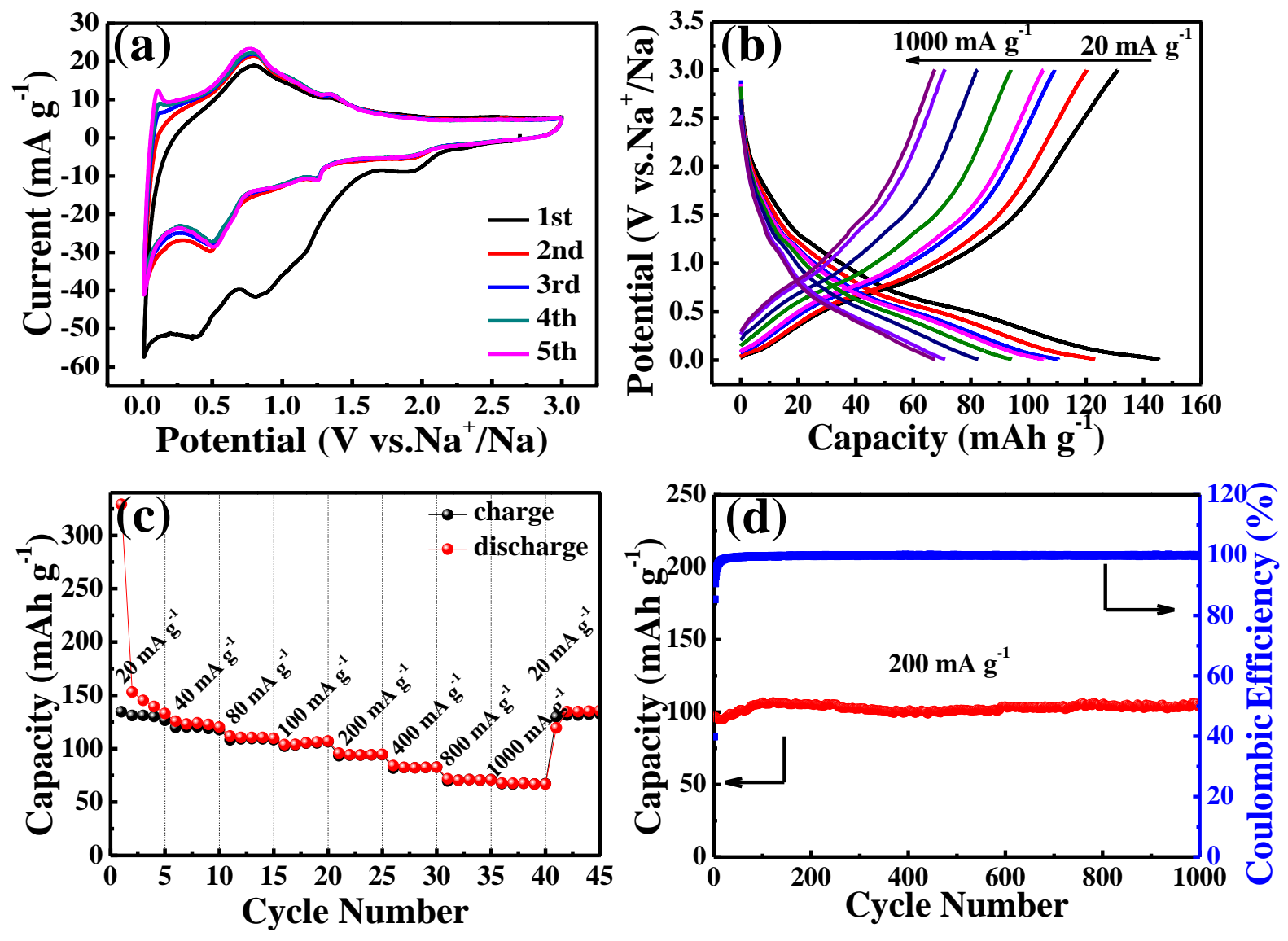

Figure 5. (a) $\mathrm{CV}$ curves of the hollandite $\mathrm{K}_{\mathrm{x}} \mathrm{TiO}_{2}$ at a scan rate of $0.1 \mathrm{mV} \mathrm{s}^{-1}$ from $0.01 \mathrm{~V}$ to $3 \mathrm{~V}$ vs. $\mathrm{Na}^{+} / \mathrm{Na}$. (b) Discharge and charge curves of the hollandite $\mathrm{K}_{\mathrm{x}} \mathrm{TiO}_{2}$. (c) Rate performance and (d) cycling performance of the hollandite $\mathrm{K}_{\mathrm{x}} \mathrm{TiO}_{2}$. 


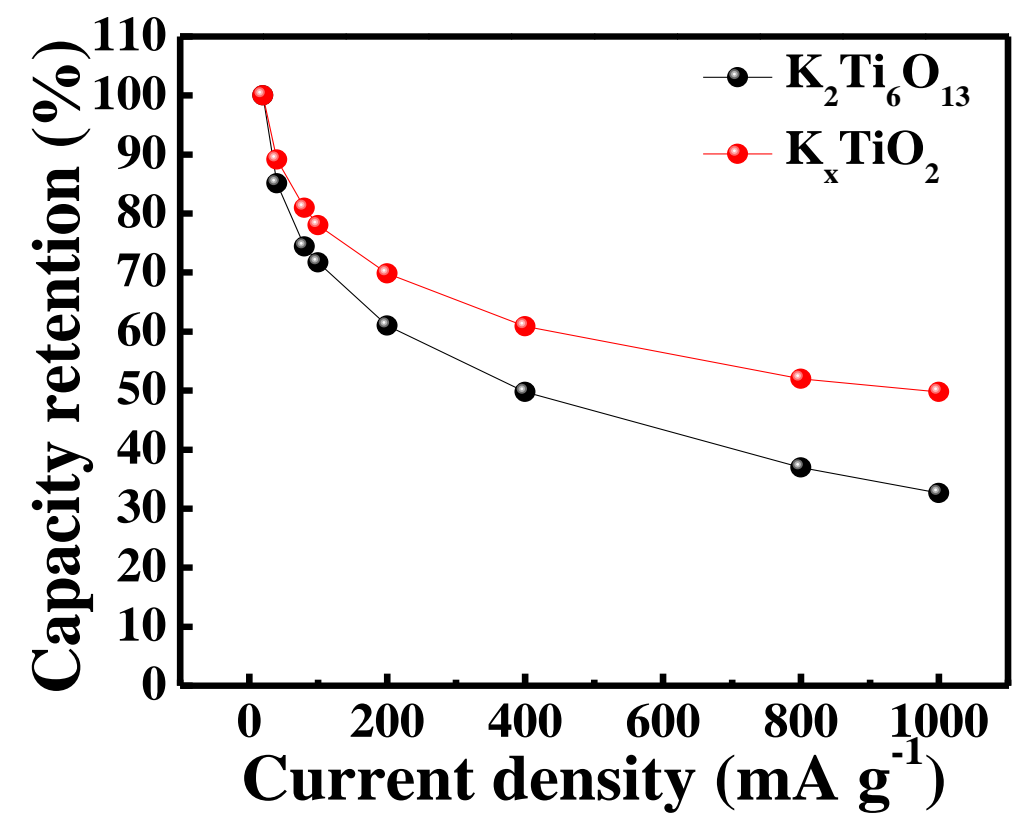

Figure 6. The rate capability comparison of low crystalline $\mathrm{K}_{2} \mathrm{Ti}_{6} \mathrm{O}_{13}$ precursor and the hollandite $\mathrm{K}_{\mathrm{x}} \mathrm{TiO}_{2}$. 

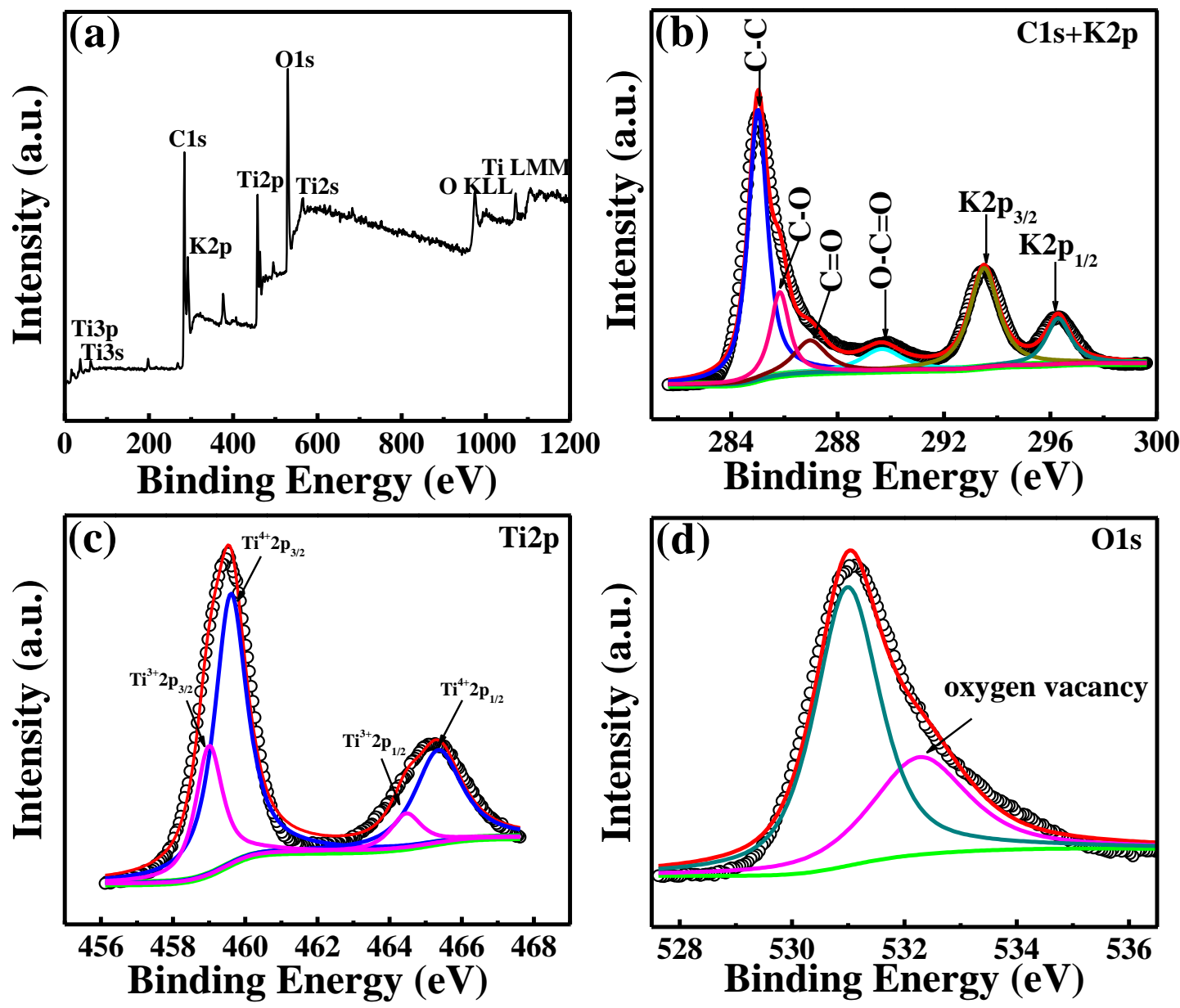

Figure 7. (a) The survey scan of XPS of the hollandite $\mathrm{K}_{\mathrm{x}} \mathrm{TiO}_{2}$. (b) High-resolution $\mathrm{C} 1 \mathrm{~s}$ and $\mathrm{K}$ 2p XPS spectrum, (c) Ti 2p XPS spectrum and (d) O 1s XPS spectrum of the hollandite $\mathrm{K}_{\mathrm{x}} \mathrm{TiO}_{2}$. 

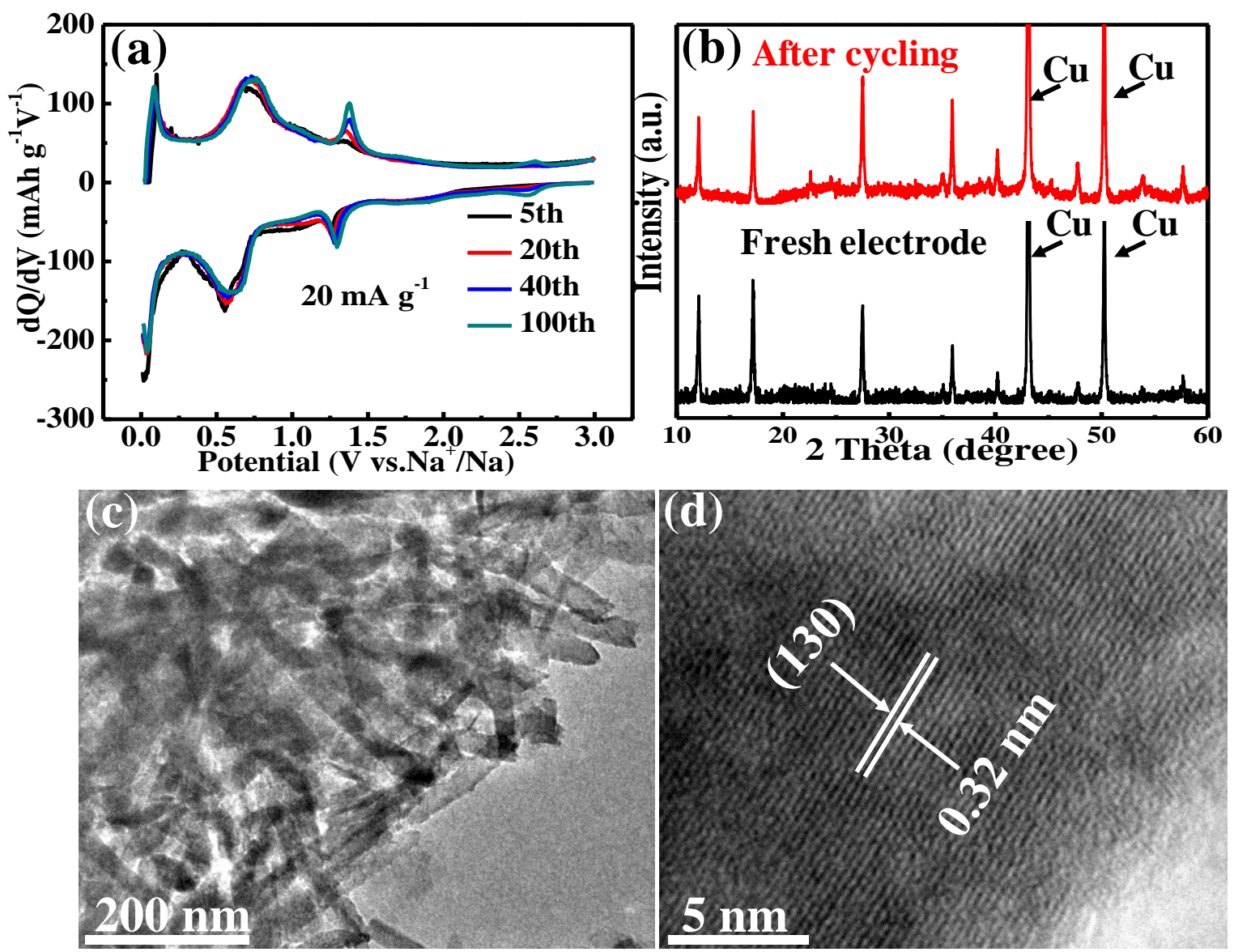

Figure 8. (a) The dQ/dV curves at $20 \mathrm{~mA} \mathrm{~g}^{-1}$ and (b) The XRD patterns of the hollandite $\mathrm{K}_{\mathrm{x}} \mathrm{TiO}_{2}$ electrode before and after cycling. (c, d) TEM image and HRTEM of the hollandite $\mathrm{K}_{\mathrm{x}} \mathrm{TiO}_{2}$ electrode after 50 cycles at $200 \mathrm{~mA} \mathrm{~g}^{-1}$. 


\section{Table of Contents}

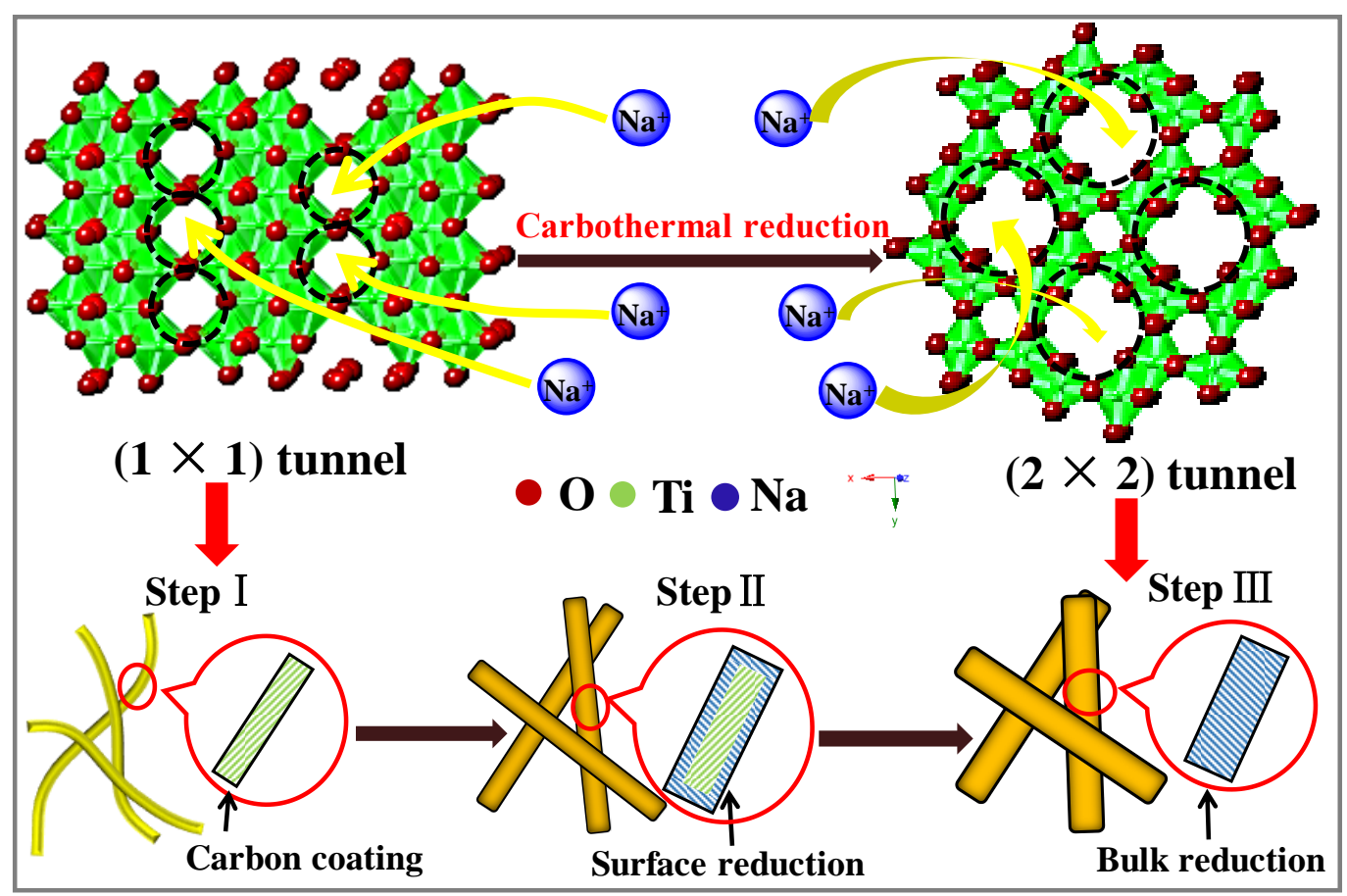

A new tunnel-structured $\mathrm{K}_{\mathrm{x}} \mathrm{TiO}_{2}$ nanorods with open $(2 \times 2)$ tunnels are successfully obtained by a mild cost-saving in-situ carbothermal reduction route. When carbon source is introduced to the heat treatment process, the reducing power of carbon leads to the generation of oxygen vacancy on the surface of $\mathrm{K}_{2} \mathrm{Ti}_{6} \mathrm{O}_{13}$, which promoted the bulk phase transformation from $(1 \times 1)$ tunnel $\mathrm{K}_{2} \mathrm{Ti}_{6} \mathrm{O}_{13}$ to $(2 \times 2)$ hollandite $\mathrm{K}_{\mathrm{x}} \mathrm{TiO}_{2}$. Attributed to the larger open tunnels of hollandite structure, the introducing of Ti(III) and oxygen vacancy, and existence of surface carbon coating layer, the $\mathrm{K}_{\mathrm{x}} \mathrm{TiO}_{2}$ exhibits large capacity, superior rate performance and long cycle stability. 